\title{
Membangun Kebiasaan Membaca pada Anak di masa Pandemi Covid-19 melalui Program Satu Jam Tanpa Gawai di Griya Baca Desa Karangrejo
}

Muh. Aniar Hari Swasono ${ }^{*}$, An Immatus Sa'diyah², Risdia Eka Nia Fitri ${ }^{3}$, Rohmania Hidayanti ${ }^{4}$

1,2,3,4,5 Universitas Yudharta Pasuruan

*Corresponding author

E-mail: aniarhari@yudharta.ac.id (Muh. Aniar Hari Swasono)*

Article History:

Received: 20-8-2020

Revised: 8-9-2020

Accepted: 9-9-2020

Keywords:

Abstract: Mulai akhir tahun 2019 lalu dunia dilanda pandemi virus yang disebut Covid-19, dimana Indonesia pun mengalami dampak pandemi virus ini yang menyebabkan perubahan sistem di berbagai bidang termasuk di dunia pendidikan. Pada saat pandemi Covid-19, proses pembelajaran dilakukan dengan memberikan materi dan tugas melalui gadget online mulai dari jenjang Taman Kanak-kanak yang menyebabkan intensitas penggunaan perangkat semakin meningkat. Warga dan pemuda di Dusun Karang Tengah memiliki pola pikir yang maju dan kreatif dalam mengurangi penggunaan gadget saat pandemi Covid-19. Mereka keluar dan warga memiliki ide untuk membuat rumah baca guna mengurangi penggunaan gadget untuk anak-anak di RT 3. Saat ada Tim Pengabdian datang ke Desa Karangrejo, pembuatan rumah baca masih dalam proses, namun setelahnya dalam beberapa hari, rumah baca bisa ditempati dengan kondisi lautnya. Setelah bekerja sama dengan tokoh masyarakat disana, kami juga berusaha mewujudkan rumah baca dengan membuat sistem dan menyediakan kebutuhan yang dibutuhkan untuk rumah baca ini. Dalam sistem rumah baca ini, kami menggunakan metode Asset Based Community Development (ABCD) dimana kami mencoba menumbuhkan minat baca pada anak-anak dalam mengurangi penggunaan perangkat selama pandemi ini. Selama proses pendampingan yang Tim Pengabdian lakukan, terjadi peningkatan minat baca pada anak-anak di Dusun Karangtengah khususnya RT 03 RW 06, dalam pembangunan rumah baca dibuat semenarik mungkin.

Rumah Baca, Gawai, Tertarik untuk Membaca 


\section{Pendahuluan}

Masa Pandemi Covid-19 ini sangat merugikan berbagai pihak dan menyebabkan kondisi Dunia menjadi mengkhawatirkan dan WHO sebut Corona saat ini merupakan Darurat Kesehatan Global. Tidak terkecuali Indonesia sudah Lebih dari 127.000 jiwa terinfeksi virus corona (Covid-19, 2020). Pemerintah melakukan berbagai upaya untuk menghentikan penyebaran virus corona mulai dari pengetesan hingga memutus rantai penularan yaitu dengan mengobati hingga isolasi di rumah sakit maupun mandiri. Tingkat keberhasilan dari penyembuhan dan penurunan penyebaran virus covid-19 tergantung dari peran serta masyarakat, mulai dari RT/RW , Desa, Kelurahan, Kecamatan hingga Dinas Kesehatan dan dibantu aparat setempat.

Kabupaten Pasuruan sempat menjadi zona merah karena tingkat infeksi Virus Covid-19 yang tinggi namun di awal bulan Agustus keadaan mulai membaik dimana yang awalnya Pasuruan menjadi zona merah menjadi zona orange dimana tingkat kasus sudah menurun tetapi masyarakat tetap harus mentaati protokol kesehatan yang berlaku saat ini. Daerah dengan Zona Orange masih belum diperbolehkan untuk melakukan pembelajaran secara tatap muka sehingga aktivitas belajar mengajar dilakukan secara daring atau online (Jatim, 2020). Pembelajaran secara daring menyebabkan intensitas penggunaan gawai semakin meningkat (Fajariyah et al., 2018). Gawai merupakan salah satu perkembangan teknologi yang pemakaiannya merata pada semua usia, termasuk anak-anak usia di bawah 5 tahun. Usia 24-60 bulan merupakan periode emas bagi anak. Pada masa ini anak memiliki peningkatan perkembangan yang cukup cepat pada aspek perkembangan, baik pada perkembangan motorik, bicara-bahasa maupun perkembangan sosialisasi-kemandirian. Penggunaan gawai yang berlebihan pada usia tersebut dapat mengganggu proses perkembangan.

Berdasarkan penelitian yang dilakukan oleh peneliti dari University Of Oxford, durasi ideal untuk melakukan aktifitas online atau gawai adalah selama 257 menit atau 4 jam 17 menit dalam sehari, sedangkan dari hasil observasi di Dusun Karang Tengah saat itu banyak anak-anak yang bermain gadget lebih dari batas waktu idealnya. Hal itu tentu dapat berdampak negatif bagi kondisi anak (Witarsa et al., 2018) menerangkan bahwa penggunaan gawai secara berlebihan akan menimbulkan kecenderungan malas untuk beraktivitas dan tidak peka dengan lingkungan sehingga mempengaruhi tingkat agresivitas anak, pola perilaku, psikososial anak. Intensitas penggunaan gawai memiliki dampak yang besar terhadap perkembangan sosialisasi-kemandirian, bicara dan bahasa gerak halus dan gerak kasar.

Dengan pola pikir warga Desa Karangrejo yang sudah maju dan kreatif sehingga munculah ide untuk membuat griya baca yang terletak di Dusun Karang Tengah untuk meminimalisir anak-anak bermain gadget terutama di RT 03 RW 06, tempat untuk griya sudah tersedia namun masih banyak kebutuhan yang belum terpenuhi seperti rak buku, buku bacaan dan berbagai peralatan tulis yang menunjang, untuk menarik minat anak supaya mau membaca dan datang ke griya 
baca penulis mendesain griya baca semenarik mungkin dengan memberikan stimulus-stimulus yang menyenangkan dan nyaman sehingga anak-anak berminat untuk datang dan membaca buku di griya baca.

Metode pembelajaran yang digunakan yaitu dengan media pembelajaran yang menyenangkan seperti halnya menggunakan media roda smart, mengajak anak untuk bermain permainan tradisional bermain lompat tali juga audio visual gerak serta mengajak anak mencintai lingkungan dengan mengajak menanam tanaman bersama dan melukis pot bunga ini semua diberikan untuk menggali kecerdasan dan emosi anak. Perkembangan tubuh melalui kegiatan yang terkoordinasi antara susunan syaraf dan otot. Salah satu aspek yang penting dalam pada proses perkembangan adalah perkembangan motorik kasar yaitu gerak tubuh menggunakan otot-otot besar, atau sebagian besar dari seluruh anggota tubuh yang dipengaruhi oleh kematangan anak sebagai awal dari kecerdasan dan emosi sosial (Ananditha et al., 2017).

Griya Baca tidak hanya terfokus pada pendidikan formal saja tetapi pendidikan karakter juga diberikan. Pendidikan karakter diberikan untuk membentuk karakter anak yang memberikan dampak positif terhadap perkembangan emosional, spiritual dan kepribadianya oleh karena itu pendidikan karakter berperan penting pada bagaimana anak bersikap dan menjalani kehidupan mereka nantinya, contoh pendidikan karakter yang diterapkan disana jujur, kreatif, mandiri, toleransi dan kerja keras. Pendidikan karakter hasilnya tidak dapat kita ketahui secara instan. Proses dan hasil upaya pendidikan dampaknya tidak akan terlihat dalam waktu yang segera, akan tetapi melalui proses yang panjang. Melalui upaya tersebut setidaknya generasi muda akan lebih memiliki daya tahan dan tangkal yang kuat terhadap setiap permasalahan dan tantangan yang datang (Maunah, 2016). Dengan adanya Griya Baca di Desa Karangrejo ini mampu mengurangi penggunaan gadget pada anak-anak di masa pandemi Covid-19 ini dan dengan adanya pendamping di Griya Baca pada setiap harinya mampu menstimulasi anak untuk datang di Griya Baca dan membaca buku setiap hari.

\section{Metode}

Pendampingan ini menggunakan pendekatan (ABCD) asset based community development, yang mengutamakan pemanfaatan aset dan potensi yang ada disekitar dan dimiliki oleh pemuda atau komunitas masyarakat di Dusun Karangtengah Desa Karangrejo kecamatan Purwosari Kabupaten Pasuruan. Salah satu modal utama dalam program pengabdian masyarakat berbasis aset adalah merubah cara pandang komunitas terhadap dirinya. Tidak hanya terpaku pada kekurangan dan masalah yang dimiliki, tetapi memberikan perhatian kepada apa yang dipunyai dan apa yang dapat dilakukan.

Dalam metode ABCD terdapat lima langkah kunci untuk melakukan riset pendampingan diantaranya adalah discovery (menemukan), dream (impian), design (merancang), define (menentukan) dan destiny (lakukan). Strategi dalam pendekatan ini diawali dengan observasi tempat dan aset yang ada untuk 
menemukan kebutuhan, kemudian melihat secara kolektif harapan dan impian masyarakat terhadap aset yang ada, setelah itu merancang sebuah kegiatan untuk mewujudkan harapan masyarakat, kemudian menentukan perubahan melalui pembentukan program, setelah itu melakukan tindakan atau pelaksanaan program yang sudah disusun.

Pendampingan ini menggunakan teori Asset Based Community Development $(A B C D)$, yang mengutamakan pemanfaatan aset dan potensi yang ada disekitar dan dimiliki oleh masyarakat. Untuk kemudian digunakan sebagai bahan yang memberdayakan masyarakat itu sendiri. Diagram ABCD kegiatan Pengabdian Kepada Masyarakat dapat dilihat pada Gambar 1.

\section{Gambar 1}

\section{Diagram Aset Based Community Development}

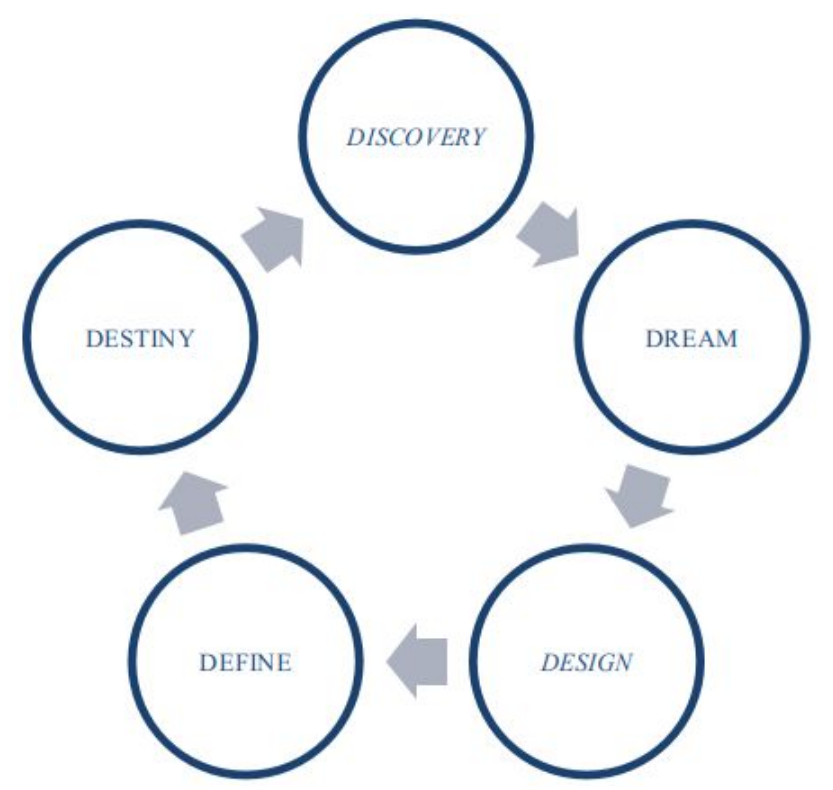

Pelaksanaan program ini berada di Desa Karangrejo, Dusun Karang Tengah RT. 3 RW. 6 dan lama pendampingan adalah mulai tanggal 19 Juli sampai 6 Agustus 2020.

\section{Hasil}

Kegiatan Pengabdian Kepada Masyarakat ini memiliki hasil sebagai berikut:

1. Discovery (menemukan kebutuhan yang ada di Griya Baca)

Pendampingan yang dilakukan di desa Karangrejo dusun Karangtengah terutama pada RT 03 RW 06 dimulai dengan observasi kepada pihak-pihak pembangunan Griya Baca yaitu kepada Bapak BPD (Badan Permusyawaratan Desa). Koordinasi yang dilakukan dengan pihak-pihak pembangunan Griya Baca. Observasi tersebut mendapatkan data bahwa berdirinya Griya Baca ini dikerjakan warga setempat dengan swadaya mereka sehingga keadaan Griya Baca pada saat itu sudah layak pakai namun masih belum memenuhi kebutuhan Griya Baca karena belum adanya peralatan tulis, buku bacaan, sarana 
mengajar, sistem pengajaran dan juga tenaga pendidik. Selain kebutuhan primer tersebut ada kebutuhan sekunder yang juga dibutuhkan untuk menarik minat baca anak-anak.

\section{Gambar 2}

\section{Kondisi Pembangunan Griya Baca}

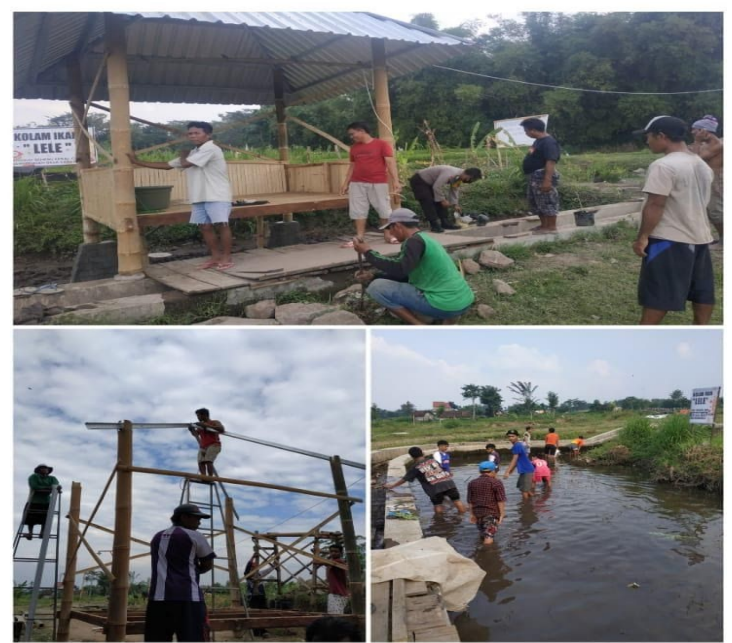

Gambar 3

Kondisi Griya Baca Sudah Jadi

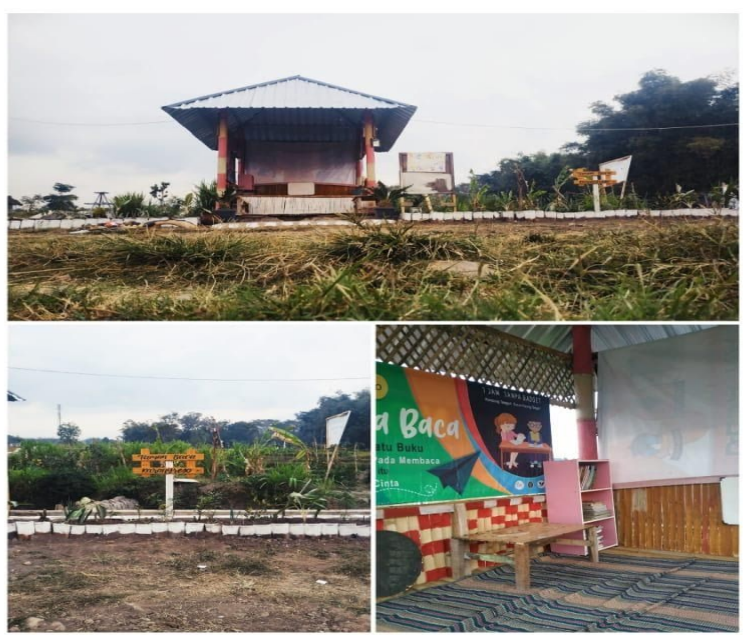

2. Dream (Melihat impian secara kolektif pada Griya Baca)

Hasil dari observasi yang telah dilakukan dapat disimpulkan bahwa dalam masa pandemi ini anak-anak kurang adanya minat belajar di rumah, maka dari itu penulis memiliki harapan bahwa meskipun anak-anak sekolah secara online akan tetapi tetap mempunyai minat yang tinggi untuk belajar secara mandiri. Informasi yang didapat dari warga karena sekolah yang dilakukan secara daring sehingga anak-anak lebih suka bermain gadget dibanding membaca buku. Griya Baca dijadikan sarana untuk meningkatkan minat belajar anak-anak khususnya dalam hal membaca, dengan harapan dalam masa pandemi ini anak-anak bukan hanya menambah pengetahuan dari buku namun juga mampu mengurangi penggunaan gawai karena dalam masa pandemi penggunaan 
gawai sudah tidak ideal lagi.

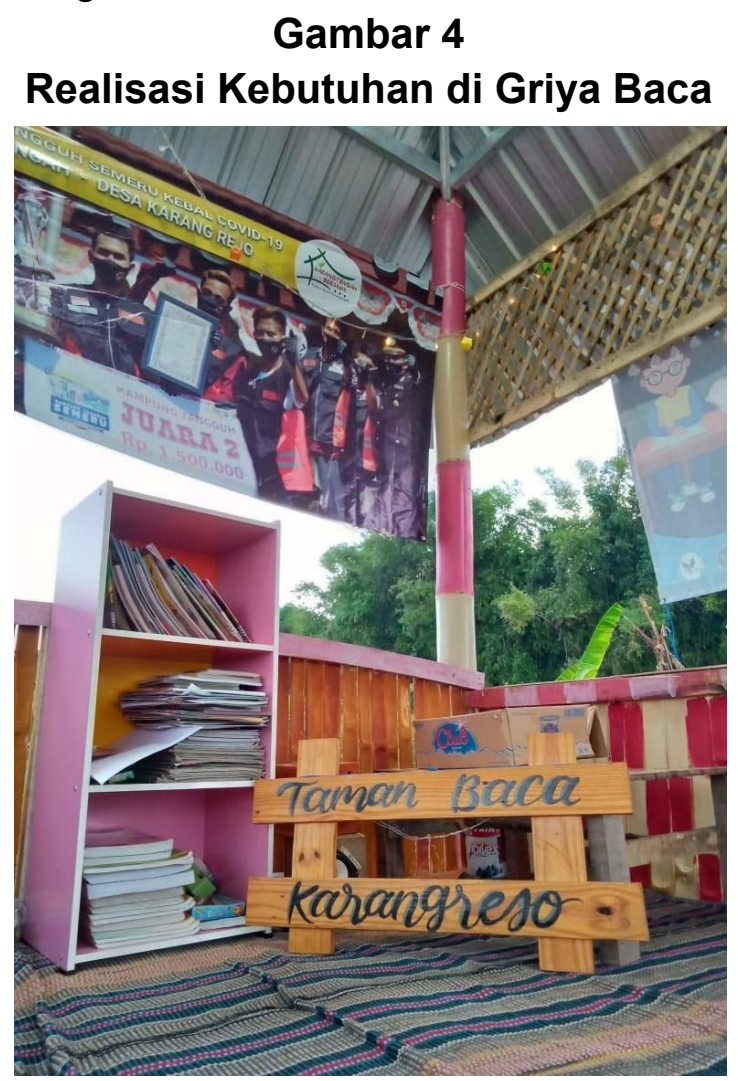

3. Design (merancang sistem di Griya Baca)

Griya Baca dibuat semenarik mungkin untuk menarik perhatian anak-anak supaya mau berkumpul. Pemberian ornamen-ornamen yang menarik dan mampu menstimulasi kognitif anak seperti lampu warna-warni, alas yang nyaman dan lucu. Media bermain juga diberikan untuk melatih sensorimotor pada anak seperti plastisin dan karet. Sistem yang penulis dan tim buat ialah "1 Jam Tanpa Gawai". Program 1 jam tanpa gawai diberikan untuk anak-anak dilakukan setiap sore hari yaitu pada pukul 16.00-17.00 WIB. Tema setiap harinya dalam pendampingan di Griya Baca berbeda-beda seperti tema dari Pendidikan Agama Islam, tema dari Psikologi pendidikan dan Pendidikan Bahasa Arab.

Program 1 jam tanpa gawai ini setiap hari terdapat kurang lebih tiga pembimbing untuk mendampingi anak-anak dalam program 1 Jam Tanpa Gawai. Penulis hanya memfokuskan membaca pada anak itu hanya 15 menit saja, karena fokus anak hanya 15 menit untuk membaca, selebihnya anak akan bosan sehingga penulis memaksimalkan waktu 15 menit itu untuk membaca, selebihnya waktu akan digunakan untuk pendidikan karakter dan bermain. Keberlanjutan program di Griya Baca nantinya akan dibentuk beberapa orang atau kader untuk meneruskan keberlanjutan program yang sudah penulis dan tim buat. 


\section{Gambar 5}

Simbolis Pembukaan Griya Baca

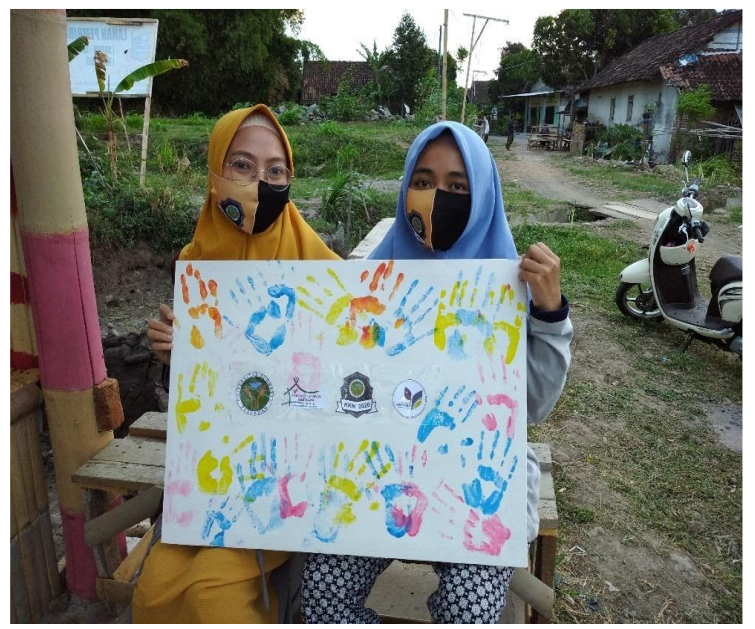

Gambar 6

Tempat yang Nyaman di Griya Baca

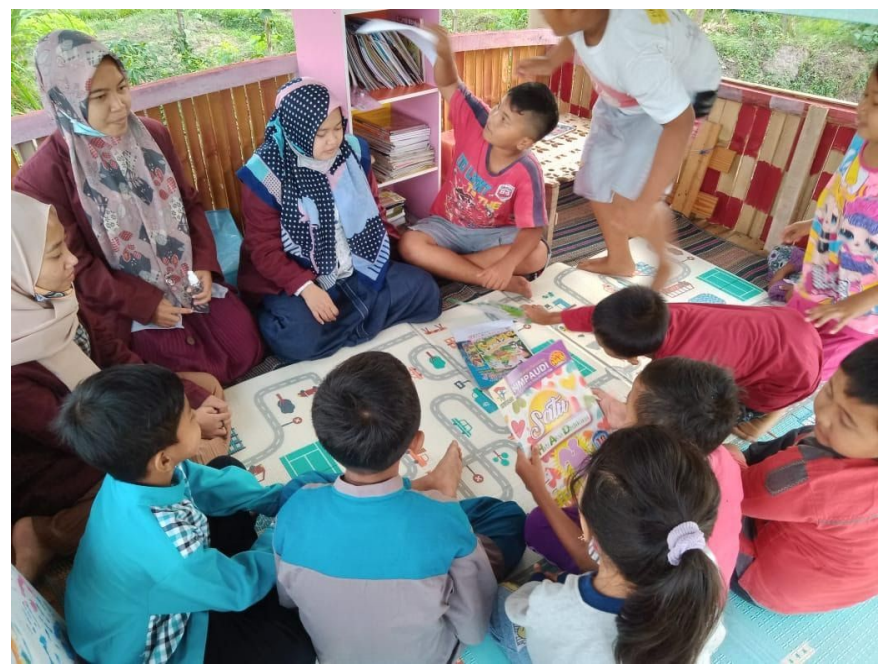

Gambar 7

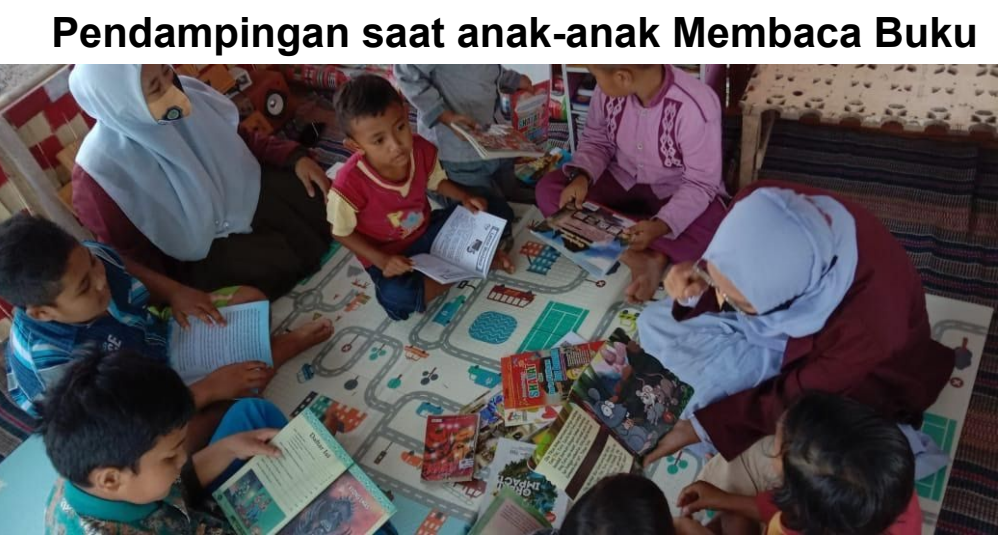

4. Define (menentukan perubahan melalui program)

Perubahan yang diharapkan setelah adanya program 1 Jam Tanpa Gawai, anak-anak di Dusun Karang Tengah terbiasa pergi ke Griya Baca untuk 
membaca buku dan mengurangi penggunaan gawai sekaligus anak dapat melestarikan permainan tradisional yang sudah disediakan disana. Sistem Griya Baca yang sudah didesain sedemikian rupa harapannya bisa di jalankan oleh kader-kader Griya Baca yang sudah dibentuk dan disepakati oleh warga Dusun Karang Tengah untuk meneruskan dan mengurus Griya Baca sehingga apa yang sudah dimulai bisa diteruskan dan dikembangkan jauh lebih baik dari kondisi Griya Baca saat ini, sehingga Griya Baca bisa menampung jumlah anak yang lebih banyak lagi supaya Griya Baca bisa dikenal dan dikunjungi anak-anak dari dusun lain.
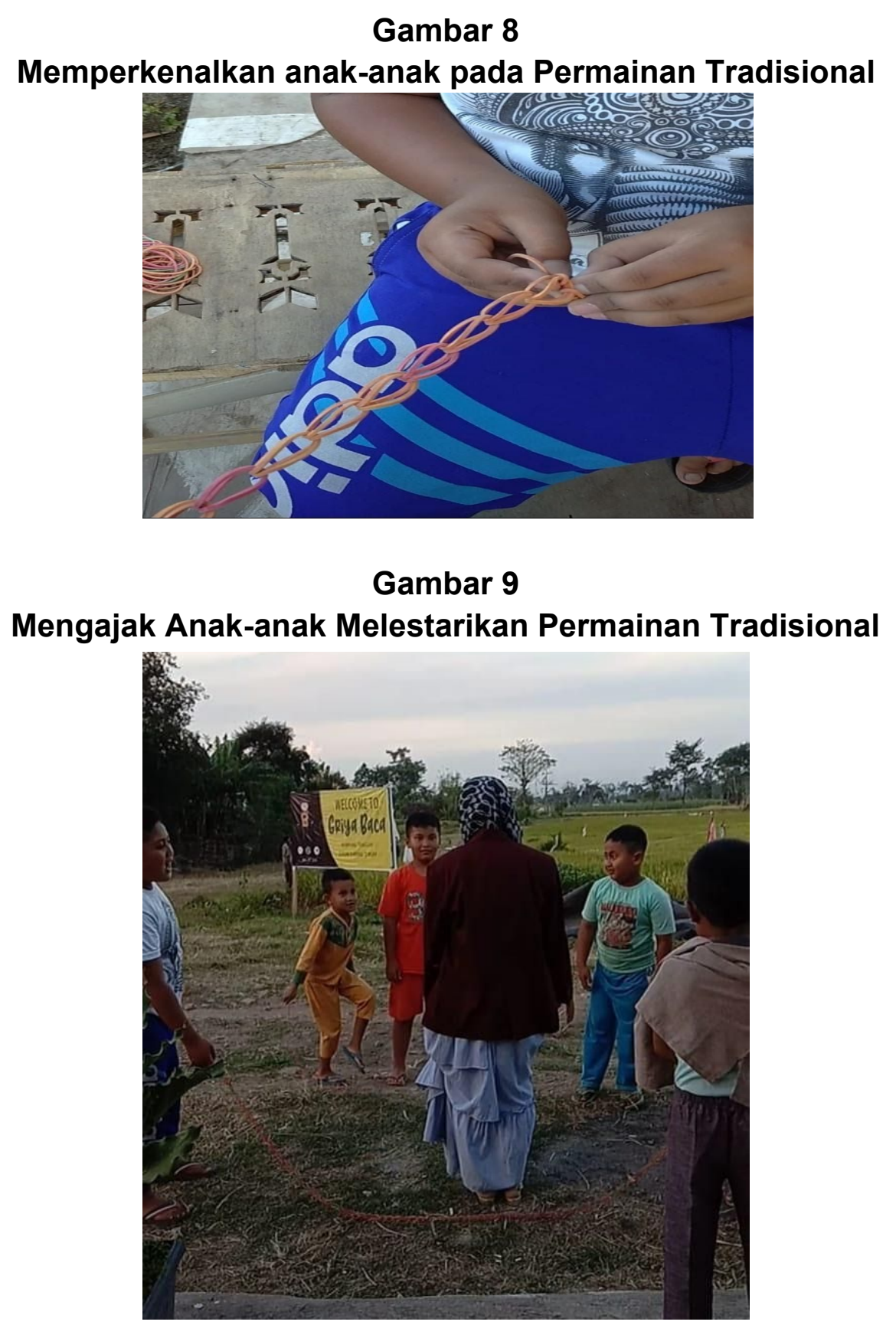


\section{Gambar 10}

Mengajak Anak Berkreasi untuk Mengecat Pot

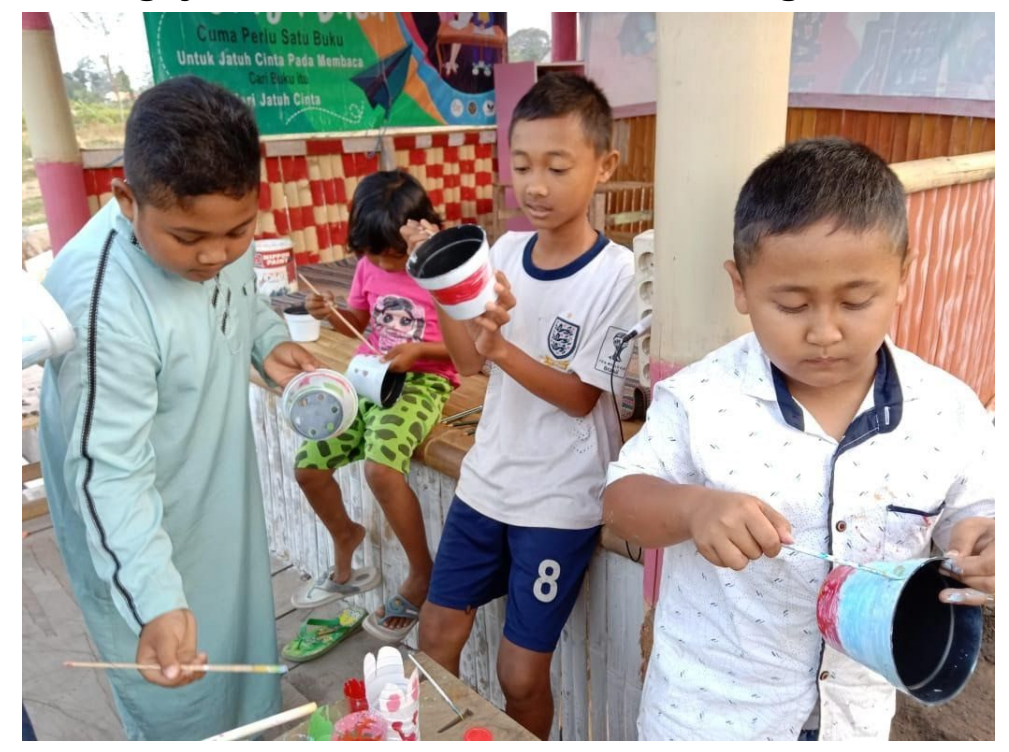

\section{Gambar 11}

Mengajak Anak Untuk Mencintai Lingkungan dengan Pembibitan

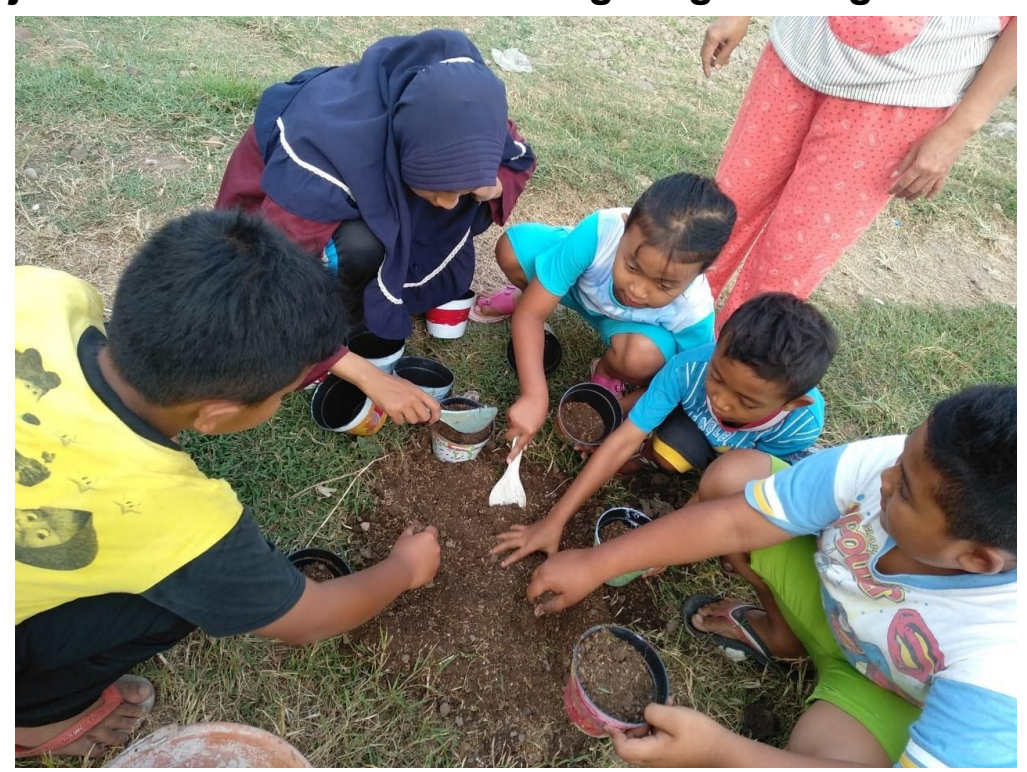




\section{Gambar 12}

\section{Serah Terima Keberlanjutan Program kepada Kader Pengelola Griya Baca}

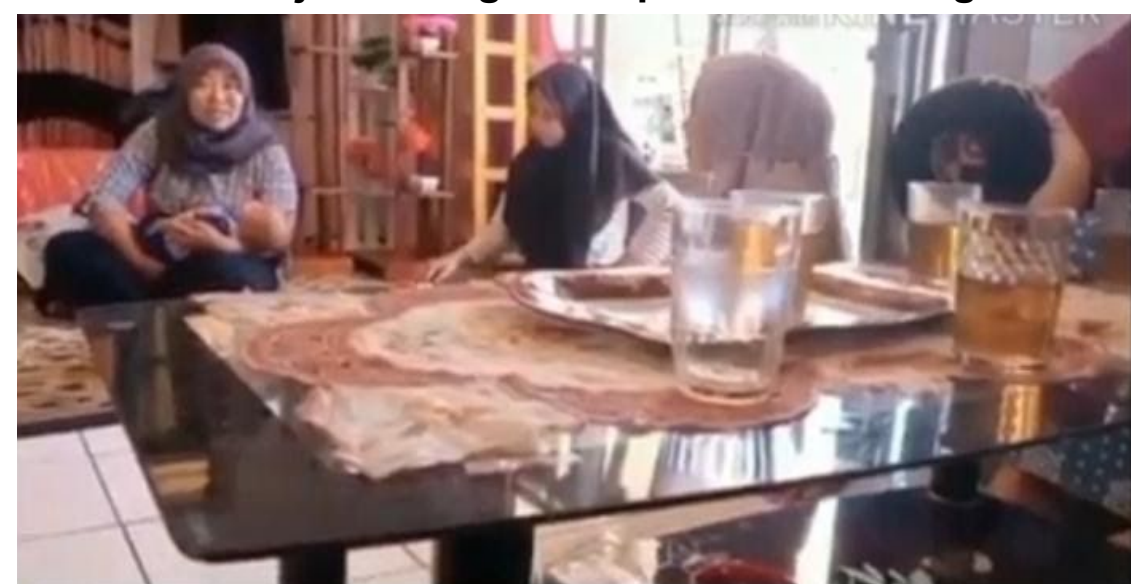

5. Destiny (Pelaksanaan Program)

Pelaksanaan program 1 Jam Tanpa Gawai ini dijalankan setiap sore hari pukul 16.00-17.00 WIB yang didampingi oleh masing-masing pendamping sesuai dengan jadwal dan tema yang sudah ditentukan. Setiap harinya ada 3 pendamping untuk anak-anak yang mau membaca di Griya Baca. Tugas pendamping yaitu untuk menciptakan suasana yang menyenangkan, memberi contoh untuk anak-anak agar rajin membaca, Membantu anak-anak menemukan buku sesuai dengan umurnya. Menunjukkan gambar-gambar menarik, Menghubungkan kisah didalam buku dengan realita dalam kehidupan, mengajak anak bermain.

Data yang penulis dan tim temukan mengenai jumlah anak yang ada di Dusun Karang Tengah yang terdiri dari 6 RT dan 2 RW terdapat 74 anak, dimana pada awal pembukaan Griya Baca dihadiri oleh anak di RT.03 yaitu terdapat 7 anak yang datang karena dari segi lokasi RT.03 yang paling dekat dari Griya Baca. Jumlah anak yang tertarik pada Griya Baca 23 anak dan jumlah anak yang tiap hari hadir di Griya baca 11 anak.

\section{Gambar 13}

\section{Kondisi Griya Baca}

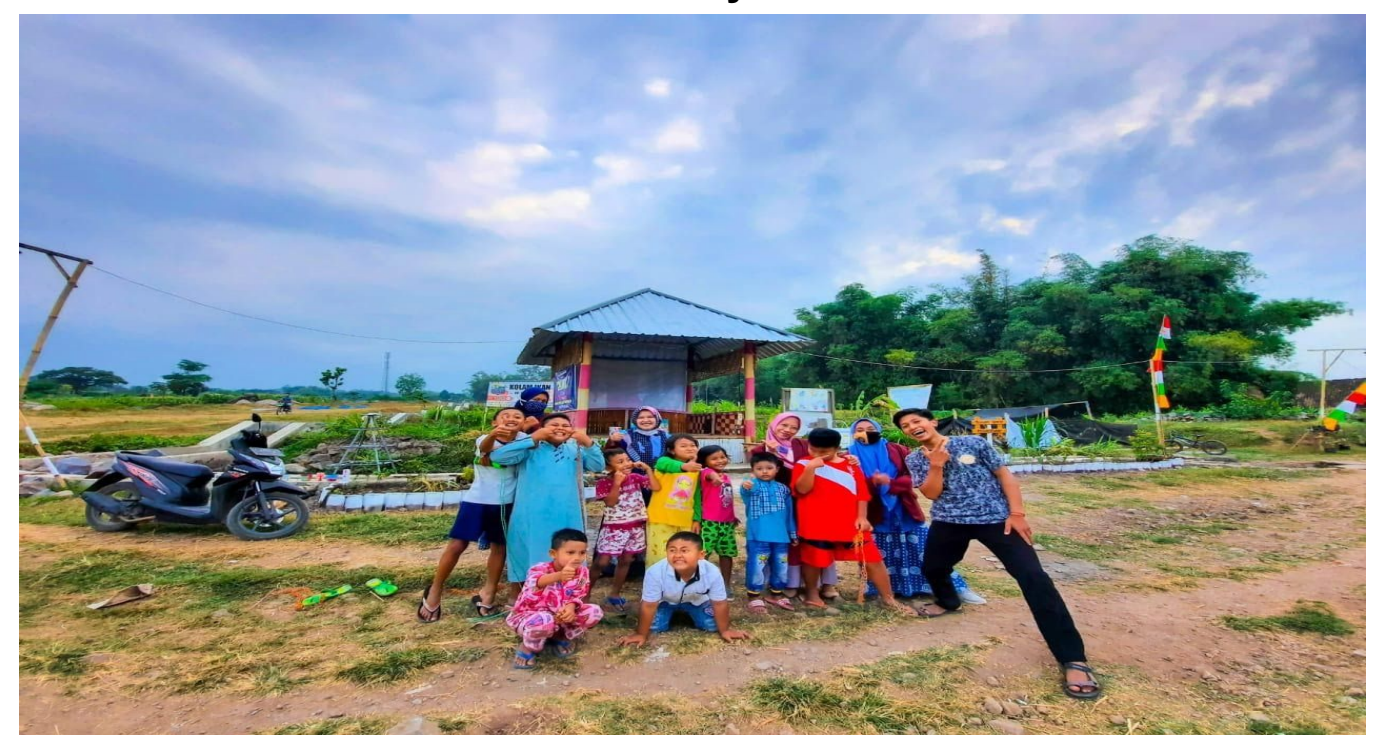




\section{Diskusi}

Membiasakan anak untuk membaca di masa pandemi covid-19 ini sangat penting, karena dalam situasi pendidikan yang serba daring atau online anak-anak akan lebih banyak menghabiskan waktu untuk penggunaan gawai dimana anak anak akan lupa bahwa belajar sumbernya bukan hanya dari gawai sehingga untuk menumbuhkan minat baca pada anak di masa pandemi ini penulis memanfaatkan aset yang ada di Desa Karangrejo tepatnya di Dusun Karang Tengah ini menjadikan sebuah Griya Baca. Aset, potensi, kekuatan dan pemberdayaan yang sangat bagus penulis lihat dari Dusun Karang tengah ini lah yang melandasi penulis menggunakan metode (ABCD) asset based community development, metode inilah yang paling tepat digunakan karena aset yang dimiliki desa akan berfungsi lebih optimal. Penggunaan aset desa menjadikan sebuah Griya Baca dengan sistem 1 jam tanpa gawai untuk membiasakan anak membaca buku. Menurut Suwarsono 2011. "perpustakaan ada baiknya memiliki ruang khusus, misalnya ruang khusus untuk anak-anak". Kutipan tersebut sangat sejalan dengan adanya Griya Baca ini dimana Griya Baca di desain senyaman mungkin semenarik mungkin untuk menarik minat anak untuk berkunjung ke Griya Baca ini. Desain untuk menarik anak untuk berkunjung ke Griya Baca pun juga diberikan stimulus-stimulus yang fungsinya untuk merangsang anak agar anak mampu tumbuh dan berkembang secara optimal ini sesuai dengan (Depkes, 2015). Setiap anak juga perlu mendapatkan stimulus sedini mungkin disetiap kesempatan demi perkembangan dan pertumbuhan anak.

Hasil dari penelitian dan observasi memang menunjukan adanya perubahan yang signifikan tentang anak yang berkunjung di griya baca, tetapi masih banyak anak yang kurang dorongan yang dapat mempengaruhi perilaku dan tindakan yang kemudian diikuti dengan perasaan senang dan ketertarikan terhadap kegiatan membaca. Minat baca sendiri harus ditanamkan sejak dini agar seseorang akrab dengan buku sedini mungkin.

Berdasarkan pendapat dari Krismanto (2009) Penilaian tinggi rendahnya minat baca dapat diketahui melalui aspek kesadaran akan manfaat membaca, perhatian terhadap membaca buku, rasa senang terhadap membaca buku dan frekuensi membaca buku. Griya Baca mempunyai sistem yang sangat menyenangkan karena pada dasarnya anak hanya difokuskan membaca buku itu kisaran 15 menit saja selebihnya anak akan diberikan materi lain. Didukung juga oleh pernyataan Direktur Pusat Neurosains Universitas Muhammadiyah Prof Dr Hamka (Uhamka) dr Rizki Edmi Edison menganjurkan, "setiap 20 menit penyampaian pelajaran, siswa diberi waktu istirahat dengan disuruh bergerak, berdiri atau berjalan sehingga dalam beberapa menit anak-anak kembali duduk menerima pelajaran dengan konsentrasi”. Program yang tidak berbasis bacaan pun penulis berikan seperti kunjungan ke suatu tempat, pemutaran video edukasi anak, permainan edukatif itu semua diberikan kepada anak selain untuk melatih gerakan sensorimotor juga untuk menanggulangi kebosanan anak-anak, sehingga kebosanan anak-anak terhadap buku tidak terjadi namun malah sebaliknya anak-anak sangat senang berkunjung di Griya Baca. 


\section{Kesimpulan}

Berdasarkan analisis data, pembahasan hasil penelitian, khususnya analisis data seperti yang telah diuraikan dalam pembahasan mengenai membangun kebiasaan anak membaca melalui program 1 jam tanpa gawai di Griya Baca Desa Karangrejo Dusun Karang Tengah maka penulis dapat menyimpulkan, bahwa hasil observasi dan pengujian membangun kebiasaan anak terhadap membaca buku melalui program 1 jam tanpa gawai di Griya Baca, diketahui ada pengaruh yang signifikan terhadap peningkatan jumlah anak yang berkunjung dan menjadi penghuni tetap griya baca untuk membaca buku setiap harinya dari awal hanya 2 anak hingga akhir kegiatan lebih dari 10 anak yang hadir dan mengikuti kegiatan di rumah baca sehingga dengan membangun kebiasaan anak untuk membaca buku mampu mengurangi intensitas penggunaan gawai pada anak.

\section{Pengakuan/Acknowledgements}

Penulis menyadari bahwa dalam penulisan jurnal ini tidak sedikit hambatan yang merintangi. Hanya berkat rahmat dari Allah SWT, serta dorongan dan bantuan dari berbagai pihak, akhirnya jurnal ini selesai tepat pada waktunya. Oleh karena itu penulis ingin menyampaikan rasa terima kasih yang tak ternilai harganya kepada semua pihak yang telah turut serta membantu penulis hingga terselesainya jurnal ini terutama kepada:

1. Rektor Universitas Yudharta Pasuruan yang selalu rela meluangkan waktu beliau untuk selalu memberikan bimbingan dan motivasi untuk melaksanakan program Pengabdian di Desa Karangrejo Kecamatan Purwosari.

2. Kepala Desa Karangrejo beserta segenap Perangkat Desa Karangrejo yang sudah berkenan mengizinkan penulis dan tim untuk melaksanakan pengabdian masyarakat di Desa Karangrejo tepatnya Dusun Karangtengah.

3. Seluruh Masyarakat Desa Karangrejo Dusun Karang Tengah yang sudah berkenan menerima dan mendukung untuk melaksanakan pengabdian masyarakat.

4. Tim penulis, yang telah membantu dan sudah menjalin kerjasama dan kekompakan dalam menjalankan pengabdian masyarakat.

\section{Daftar Referensi}

Ananditha, A. C., Kesehatan, F. I., \& Muhammadiyah, U. (2017). Faktor-faktor Yang Berhubungan Dengan Perkembangan. Jurnal Keperawatan Muhammadiyah 2(1)2017 Faktor-faktor, 2(1).

Covid-19, S. T. (2020). Data Sebaran Covid-19. Dipetik Agustus 11, 2020, dari https://covid19.go.id

Depkes. (2015). Fortune t.a.v. Peter Verloop Dijk 182731 AA Benthuizen. 27-29.

Djamarah. (2008). Psikologi Belajar. Jakarta: Rineka Cipta.

Fajariyah, S. N., Suryawan, A., \& Atika, A. (2018). Dampak Penggunaan Gawai

Terhadap Perkembangan Anak. Sari Pediatri, 20(2), 101. https://doi.org/10.14238/sp20.2.2018.101-5 
JPM: Jurnal Pengabdian kepada Masyarakat Institut Teknologi dan Bisnis Asia Malang Vol. 1, No. 2, November 2020, pp. 38-50

Jatim, S. T.-1. (2020). Radar Peta Sebaran. Dipetik Agustus 11, 2020, dari https://infocovid19.jatimprov.go.id/

Lukman, A. D. (1996). Kamus Besar Bahasa Indonesia (II ed.). Jakarta: Balai Pustaka.

Maunah, B. (2016). Implementasi Pendidikan Karakter Dalam Pembentukan Kepribadian Holistik Siswa. Jurnal Pendidikan Karakter, 1, 90-101. https://doi.org/10.21831/jpk.v0i1.8615

Witarsa, R., Mulyani, R. S., Urhananik, \& Haerani, N. R. (2018). Pengaruh penggunaan gadget terhadap kemampuan interaksi sosial siswa sekolah dasar. Pedagogik, VI(1), 9-20. 